\title{
SPATIO-TEMPORAL THERMAL FRONTS DISTRIBUTION DURING JANUARY-DECEMBER 2018 IN THE MAKASSAR STRAIT: AN IMPORTANT IMPLICATION FOR PELAGIC FISHERIES
}

\author{
Mukti Zainuddin ${ }^{1 *}$, Achmar Mallawa ${ }^{1}$, Safruddin $^{1}$, St. Aisjah Farhum ${ }^{1}$, Rachmat Hidayat $^{1}$, Andi Rani \\ Sahni Putri ${ }^{1}$, Muhammad Ridwan ${ }^{2}$
}

Submitted: March 17, 2020 Accepted: March 30, 2020

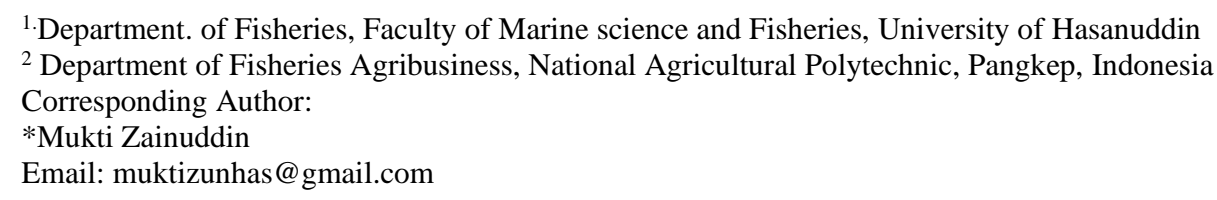

\section{ABSTRACT}

Makassar Strait has been identified as an area of interesting studies for marine science and operational fisheries. It provides the unique ocean structures such as topographic feature, the main path of the Indonesia Throughflow (ITF) and dynamics of thermal fronts. The aims of this study were to map the dynamic spatial and temporal of the thermal fronts, and to describe their implications to the pelagic fisheries. We used satellite data of sea surface temperature (SST) for the period of January-December 2018 with spatial and temporal resolutions of $4 \mathrm{~km}$ and monthly, respectively. For fishery data, we used sampling data of skipjack tuna fishing ground distributions in October and December 2018. Thermal fronts throughout the year were estimated using a Single Image Edge Detection (SIED) algorithm and the available fishing ground data were overlain on the SST front map. The results showed that the spatial distributions of thermal fronts along Makassar Strait tended to be different every month. However, the thermal fronts were consistently detected near the upwelling area from June to September. Skipjack tuna fishing grounds associated with fish aggregating devices (FADs) developed in the northern area of upwelling in October. Two month later, the FADs and free swimming skipjack fishing grounds again well formed around the same location. It implies that the formation of the thermal fronts after upwelling contributes the positive effect on development of pelagic fishery especially skipjack in Makassar Strait.

Keywords: thermal front, SIED, pelagic species, Makassar Strait

\section{INTRODUCTION}

Makassar Strait plays an important role related to marine science and operational fisheries oceanography. It provides the unique ocean structures such as variability of the topographic feature, the main path of the Indonesia Throughflow (ITF) (Gordon, 2005; Gordon et al., 2008), important upwelling zone associated with the southeast monsoon winds (Hendiarti et al., 2005; Atmadipoera and Widyastuti, 2014) and dynamics of the oceanic fronts (Hidayat et al., 2019). This area is also characterized by spatial distribution locations of both cyclonic and anti-cyclonic eddy (Nuzula et al., 2017; Hidayat et al, 2019). The spatial dynamics of the physical oceanographic structures in this area results in a highly productive habitat, which serves as a good fishing ground for various commercially and ecologically important species, such as skipjack tuna (Katsuwonus pelamis), flying fish Hirundichthys oxycephalus and mackerel (Rastrelliger kanagurta) (Zainuddin, 2011; Putri and Zainuddin, 2019; Hidayat et al., 2019; Nurdin et al., 2017).

One of important the physical oceanographic structures in Makassar Strait is the availability of thermal fronts. It seems that this has interesting spatial and temporal dynamics which may correspond with the dynamics of pelagic fishery in that area. Thermal fronts are known as important congregating spots for many valuable pelagic species (Etnoyer et al., 2004). Therefore, the objectives of this paper were to map the dynamic spatial and temporal of the thermal fronts, and to describe their implications to the pelagic fisheries using satellite remote sensing and catch data.

\section{MATERIALS AND METHODS}

Remotely sensed satellite data of SST from January to December 2018 were used to detect thermal fronts using Single Image Edge Detection (SIED) algorithm (Cayula and Cornellon, 1991). In this study, we used SST standard mapped image data level 3 with spatial resolution of approximately 4 $\mathrm{km}$ and monthly temporal resolution. The input data used for the front detection process were seasurface temperature and chlorophyll-a derived from satellite imagery. The temperature image were available in the NetCDF (NC) data format. The SST data were processed using the interactive data language (IDL) software package 8.3 to get the study area (Makassar Strait) from the global image. We then converted the floating point data into raster data format using the kriging interpolation in the 
spatial analyst of ArcGIS 10.2. The data were then changed from raster data to integer format using map algebra in the spatial analyst tools. The resulting integer data was then processed using the Marine Geospatial Ecology Tools (MGET) plugin in the ArcGIS toolbox. The MGET plugin automatically determined the lines of the thermal front, with a horizontal gradient based on specified temperature levels.

For fishery data, we used high resolution sampling data of skipjack tuna fishing ground distributions in October and December 2018. We used these data to verify the suitability of the available fishing data and the locations of the fish aggregating devices (FADs) relative to the dynamics of the thermal fronts.

\section{RESULTS AND DISCUSSION}

Based on the results throughout the year, the thermal fronts were consistently available along the Makassar Strait. In January 2018, it appeared in the
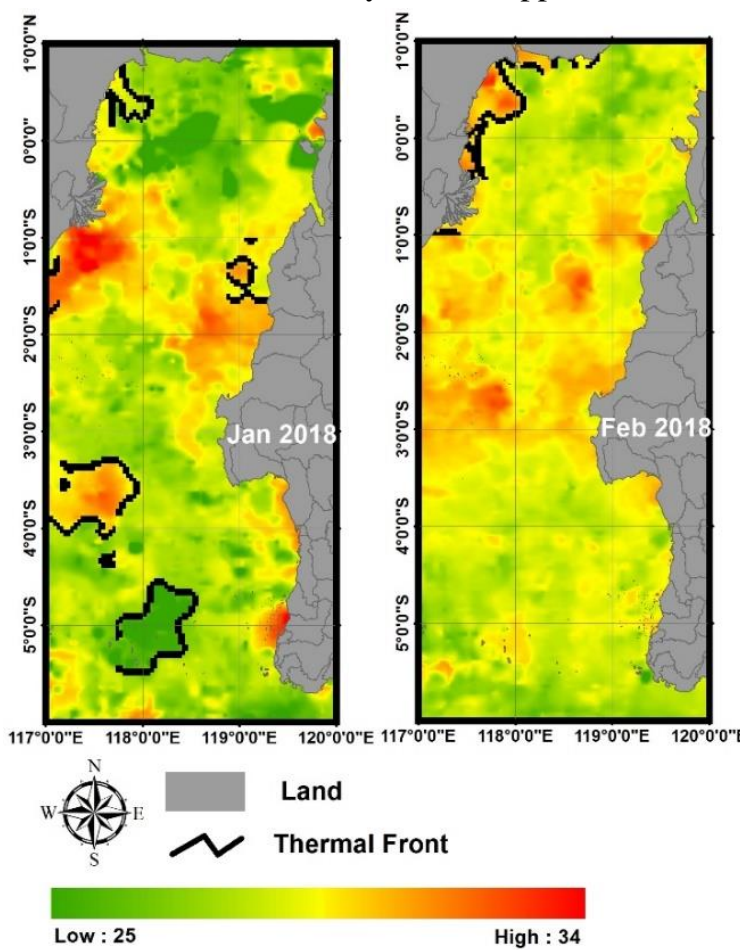

Figure 1. Spatial distribution of thermal front in Makassar Strait during January-April 2018

Figure 2 shows that thermal fronts well develop from May to August (Figure 2). In May, it appears that thermal fronts started to form particularly in the southern area of Makassar Strait near Makassar and Takalar coastal waters. The thermal fronts were clearly detected to correspond with coastal upwelling from June to September and it reaches the peak in August. These results were reinforced by the previous findings (Atmadipoera and Widyastuti, 2014). It is important to note that the development

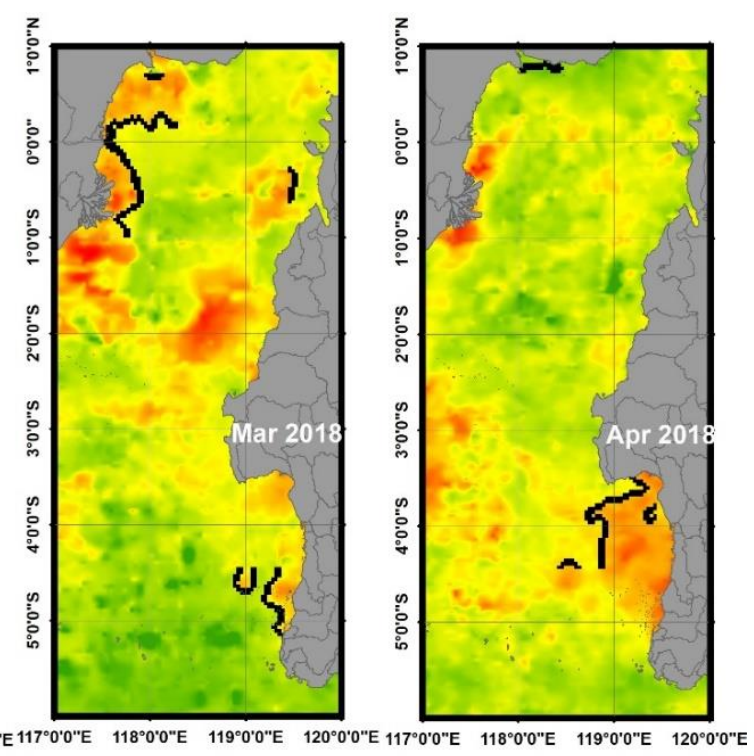

northern side closed to the coastal of East Kalimantan (Figure 1). Besides, the thermal fronts also were detected near Mamuju waters, specific area of $117^{\circ} \mathrm{E}-118^{\circ} \mathrm{E}$ and $3-4^{\circ} \mathrm{S}$ and off coast of Makassar Strait around the location of approximately $5^{\circ} \mathrm{S}$ and $118^{\circ} \mathrm{E}$. The availability of the thermal fronts has a great implication for pelagic fishery since the actual fishing data occupied the area as the main fishing grounds especially for purse seine fishing (National Marine and Fisheries Agency, 2018; Zainuddin et al., 2019). During February-March, the thermal fronts were located along the coastal areas of East Kalimantan. However, there are no fishery data confirm the areas as a good fishing ground. It is interesting point that the development of thermal fronts in the southern Makassar Strait are in good association with pelagic fisheries in the period of March-April (Nurdin et al., 2017). of the thermal fronts-associated upwelling in that
area agree well with the successful flying fish fishing using gillnet by Takalar fishermen (Zainuddin, 2011). The previous investigation found that the flying fish fishing reach a peak in July, one month earlier than the peak of upwelling phenomenon (Zainuddin 2011). Besides, the thermal fronts were also showed around the Mamuju and Mejene waters (west Sulawesi). The temperature fronts were proved to be associated 
with the formations of both fish aggregating devices (FADs) and liftnet fishing grounds (Zainuddin and Ridwan, 2017).
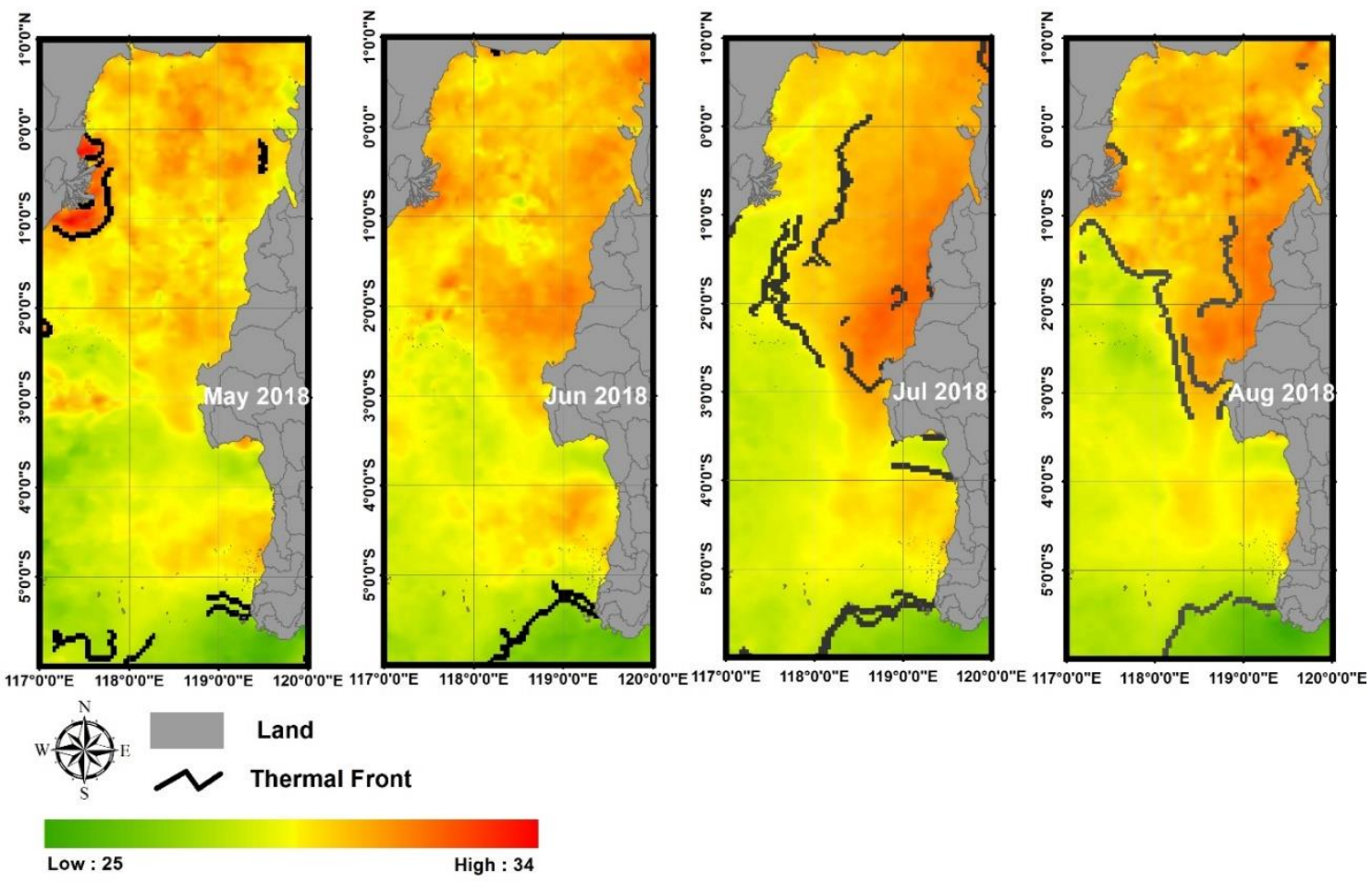

Figure 2. Spatial distribution of thermal front in Makassar Strait during May-August 2018

For the period of September-December, the thermal fronts were varied spatially and temporally every month (Figure 3). In September, they were detected in the northern Mamuju waters. It seems that the area covered by the temperature fronts are in accordance with the potential predicted area for large pelagic fish around the Mamuju waters (Safruddin et al., 2017). In this month, the upwelling-based thermal front indicator still appeared. The interesting point for this result (Figure 3) is that the appearance of thermal fronts in the southern Makassar Strait could be confirmed by the development of pelagic fishery particularly at the positions of the FAD (Figure 4: left). Skipjack tuna catches are mainly captured around the sharp gradient temperature fronts. The availability of the thermal fronts is an important indicator for detecting large pelagic fish and it could significantly increase tuna catch per unit effort (Nieto et al., 2017). Two months later, in December, the fishery data proved that both the FADs and free swimming schools of skipjack have a good association with the thermal fronts in the areas of around the Barru, Parepare and Polman coastal waters (Figure 4: right). The development of pelagic fishery in those areas may have a link with the thermal front and upwelling in which provide a good feeding opportunity for skipjack tuna. All these facts suggest that the availability of the thermal fronts can improve the successful fishing especially as a good indicator for detecting pelagic fishing grounds. 


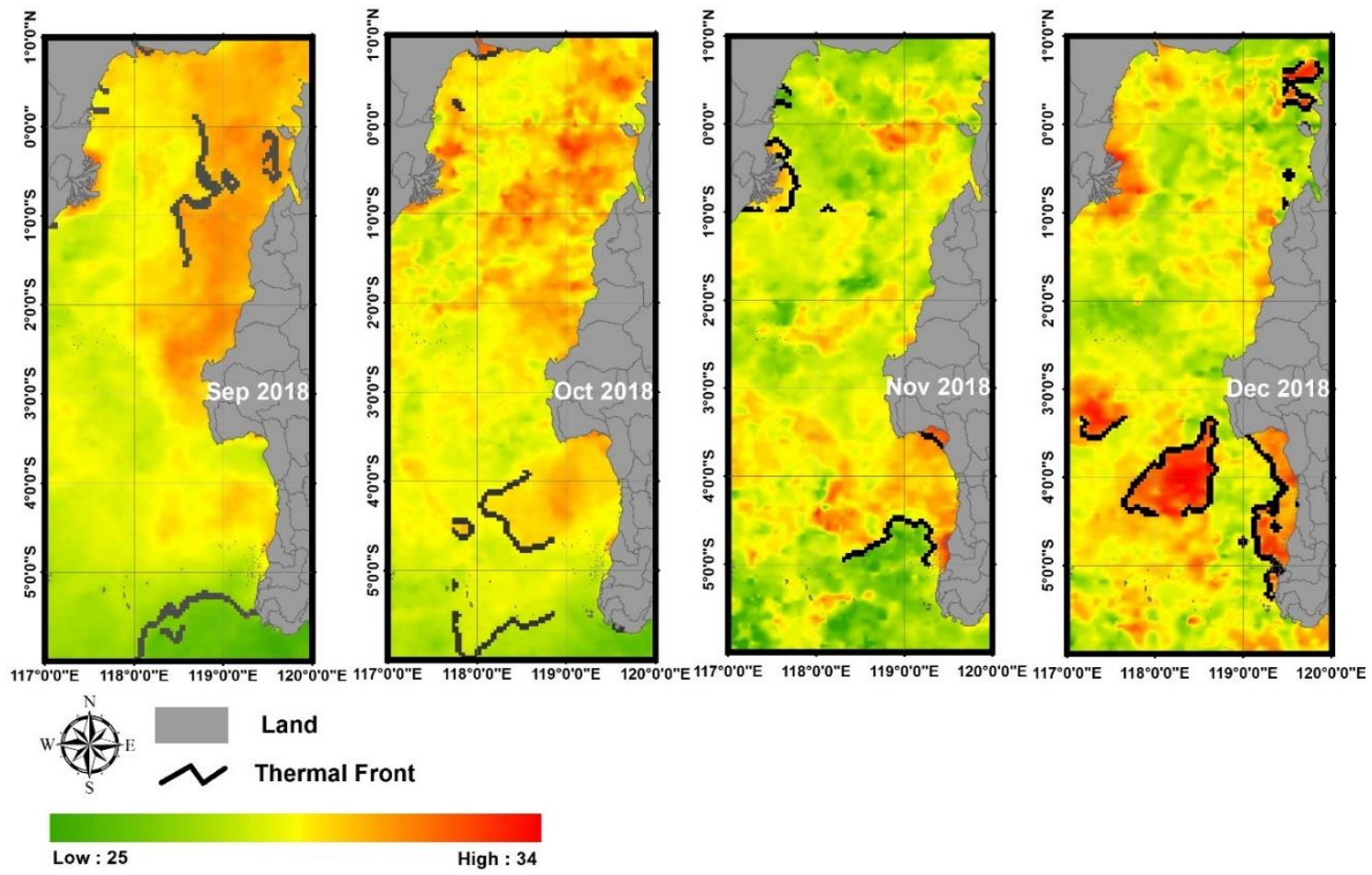

Figure 3. Spatial distribution of thermal front in Makassar Strait during September-December 2018

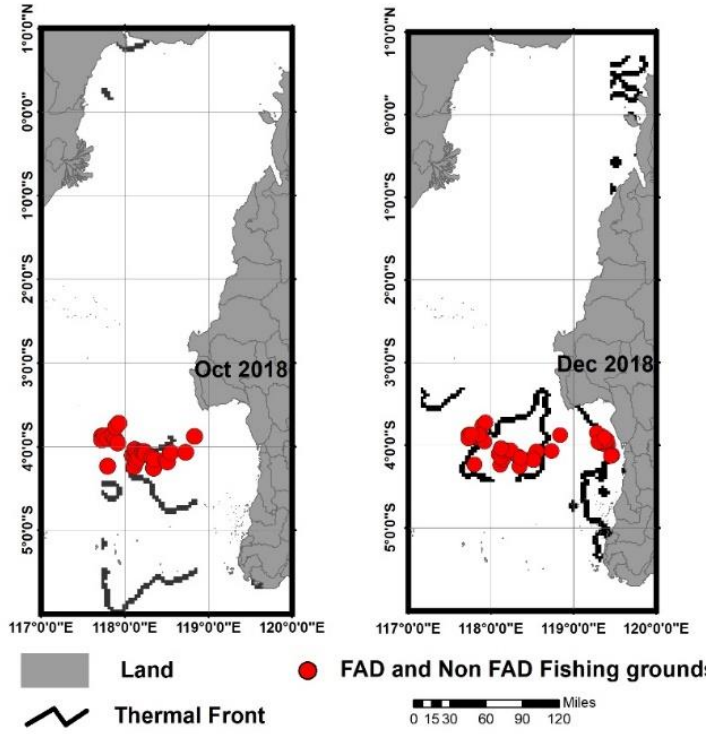

Figure 4. Spatial distributions of skipjack tuna fishing grounds associated with the FAD (left) and free swimming schools (right) in Makassar Strait.

\section{CONCLUSION}

The locations of thermal front were mostly appeared in the southern Makassar Strait. The thermal fronts can be a good indicator for detecting upwelling area which plays an important role for development of pelagis fishery. The availability of the thermal fronts in that area has a positif implication to detect potential fishing grounds for pelagic fishery such as skipjack tuna fishery.

\section{ACKNOWLEDGMENT}

We acknowledge the NASA ocean color for providing SST dataset through website https://oceancolor.gsfc.nasa.gov/. Specifically, we thank to Kemenristek DIKTI for supporting the research grand (PTUPT) in 2019.

\section{REFERENCES}

Atmadipoera AS and Widyastuti P. 2014. A Numerical Modeling Study on Upwelling Mechanism in Southern Makassar Strait. Jurnal Ilmu dan Teknologi Kelautan Tropis.Vol. 6: 355-371.

Cayula J F and Cornillon P .1992. Edge detection algorithm for SST images J. Atmos. Ocean. Tech. 9: 67-80.

Etnoyer, P., Canny, D., Mate, B. and Morgan, L. 2004. Persistent pelagic habitat in the Baja California to Bering Sea (B2B) Ecoregon. J. Oceanogr. 17:90-101.

Gordon, A. 2005. The Oceanography of the Indonesian Seas and Their Throughflow. Oceanography, Vol. 18(4): 14-27. https://doi.org/10.5670/oceanog.2005.01

Gordon, A.L, R. D. Susanto, A. Ffield, B. A. Huber, W. Pranowo, and S.Wirasantosa. 2008. Makassar Strait throughflow, 2004 to 2006. Geophysical Research Letters, Vol. 35, L24605, doi:10.1029/2008GL036372. 
Hendiarti N, Suwarso , Aldrian E, Amri K, Andiastuti R, Sachoemar S, et al. Seasonal Variation of Pelagic Fish Catch Around Java. Oceanography. 2005:18(4):112-23.

Hidayat R., Zainuddin M., Putri A. R., S., Safruddin, 2019 Skipjack tuna (Katsuwonus pelamis) catches in relation to chlorophyll-a front in Bone Gulf during the southeast monsoon. AACL Bioflux 12(1):209-218.

Ministry of Marine and Fisheries Affairs of the Republic of Indonesia. 2018. Statistics Report for Marine and Fisheries Affairs of the Republic of Indonesia.

Nieto, K, Y. Xu, S. L. H.. Teo, S. McClatchie, J. Holmes, .2017. How important are coastal fronts to albacore tuna (Thunnus alalunga) habitat in the Northeast Pacific Ocean?.Progress in Oceanography, Vol. 150, 2017: 62-71.

Nurdin, S., Mustapha, M. A., Lihan, T., \& Zainuddin, M. 2017. Applicability of remote sensing oceanographic data in the detection of potential fishing grounds of Rastrelliger kanagurta in the archipelagic waters of Spermonde, Indonesia. Fisheries Research, 196 , $1-12$. https://doi.org/10.1016/j.fishres.2017.07.02 9

Nuzula F, Syamsudin ML, Yuliadi LPS, Purba NP and Martono. Eddies spatial variability at Makassar Strait-Flores Sea. IOP Conf. Ser.: Earth Environ. Sci. 2017; 54: 012079.

Putri ARS and M Zainuddin. 2019. Impact of Climate Changes on Skipjack tuna (Katsuwonus pelamis) catch during MayJuly in the Makassar Strait. IOP Conf. Ser.: Earth Environ. Sci. 253: 012046

Zainuddin, M. 2011. Preliminary Findings on Distribution and Abundance of Flying fish in Relation to Oceanographic Conditions of Flores Sea Observed from Multi-spectrum Satellite Images. Asian Fsiheries Sciences, Vol. 24:20-30.

Zainuddin M, M. Ikhsan Amir, A. Bone2, St. A. Farhum, R. Hidayat, A. R. S. Putri, A. Mallawa, Safruddin, M. Ridwan. Mapping distribution patterns of skipjack tuna during January-May in theMakassar Strait. IOP Conf. Ser.: Earth Environ. Sci. 370: 